\title{
Green Innovations in the Tourism Sector
}

\author{
Zvjezdana Gavrilović \\ Faculty of Business Economics, University of East Sarajevo, Bijeljina, Republic of Srpska, Bosnia and Herzegovina \\ Mirjana Maksimović \\ Faculty of Electrical Engineering, University of East Sarajevo, East Sarajevo, Republic of Srpska, Bosnia and Herzegovina
}

\begin{abstract}
Knowing that the tourism sector is able to generate significant social, economic and cultural benefits and development, looking for novel ways to improve this sector is more than justified. The tourism industry has not been immune to evolving advancements in Information and Communication Technologies (ICTs). Novel technology solutions and approaches have potential to significantly revolutionize this sector, making the vision of smart tourism omnipresent. Going further by investing in the greening of the tourism sector, sustainable, smart and green tourism will soon become reality. Protected environment and preserved cultural heritage and natural assets through the reduced usage of energy and reduced hazardous pollutants will consequently lead to economically, socially and environmentally sustainable tourism sector. These three components, green building, green energy and green waste are at the same time parts of the green management concept. Hence, to realize a vision of successful green tourism, it is essential to perform adequate green management implementations, including certain marketing efforts, namely green marketing. This paper presents an analysis of various greening processes of tourism sector with the help of ICTs and highlights the importance of green management and green marketing in achieving smart, green and sustainable tourism sector.
\end{abstract}

Keywords

Green ICT, green management, green marketing, environment, tourism.

\section{Introduction}

The advancements in Information and Communication Technologies (ICTs) have dramatically transformed all industries and sectors. Even though the tourism and travel industries are not seen as the quickest adopters of technology, they are very information intensive and the novel ICT solutions, especially Internet of Things (IoT) (a worldwide network of intercommunicating physical objects/"things") have revolutionized these sectors more than any other factor in the last few decades (Iyer, Chakraborty, \& Dey, 2015). Due to the numerous diverse connectable devices and interconnecting people and things anytime, at any place, with anything and anyone (ideally using any way and any service) alongside automatically collected data, completely new services and features appear, holding the potential to generate enormous market opportunities as well as make people lives smarter and more sustainable (Nitti, Pilloni, Giusto, \& Popescu, 2017). In other words, facilitating information generation, dissemination and distribution through the latest technology innovations make smart tourism vision omnipresent, improving operational efficiencies in this sector and customer satisfaction (Maksimovic \& Gavrilovic, 2016). Hence, many hospitality and travel companies are investing heavily in novel ICT solutions, placing the customer at the first place (Morris, 2016). According to Columbus (2016) the travel, transportation, and hospitality industry are leading the way in IoT implementation with average IoT spend per company in 2015 (\$128.9 million) and as a percentage of revenue $(0.60 \%)$ across all thirteen industries surveyed (Table 1). The tourism industry has significant potential to be a key factor in the world economy growth (United Nations Environment Programme and World Tourism Organization, 2012). While the direct contribution of travel and tourism was $\$ 2,155.4$ billion in 2013 , it is predicted that it will rise by 4.2 percent annually in 2014-2024, to $\$ 3,379.3$ billion in 2024 (World Travel \& Tourism Council, 2016). 
However, simply implementing novel technologies and making tourism smart is not enough in the process of creating the tourism as the world's largest industry. It is more important to make the tourism and travel industries sustainable. Knowing that the tourism sector is responsible for $5 \%$ to $12 \%$ of global greenhouse gas (GHG) emissions (Peeters \& Dubois, 2010) it is mandatory to work and accept term sustainable tourism from both tourists and tour operators (Nitti et al., 2017). Economically, socially and environmentally sustainable fast growing tourism sector can be achieved only by using recyclable or renewable technologies, protecting the environment, respecting local cultures, improving local communities, involving businesses, staffs and tourists in sustainable practices, minimizing energy usage and pollution and conserving cultural and natural assets. Therefore, this paper analyses the processes of making the tourism sector smart and at the same time sustainable through implementing green ICTs and adequate management and marketing efforts.

Table 1 The loT spending metrics by industry

\begin{tabular}{|c|c|c|c|}
\hline \multicolumn{4}{|c|}{$\begin{array}{l}\text { Q9 (Global Industries): Average Industry Spend on loT } \\
\text { Initiatives as a percentage of Company Revenue }\end{array}$} \\
\hline Industry & $\begin{array}{l}\text { Average } \\
\text { loT } 2015 \\
\text { Spend } \\
\text { Per } \\
\text { Compa- } \\
\text { ny (in \$ } \\
\text { millions) }\end{array}$ & $\begin{array}{l}\text { Average } \\
\text { revenue Per } \\
\text { Compa- } \\
\text { ny/lndustry } \\
\text { (in \$ mil- } \\
\text { lions) }\end{array}$ & $\begin{array}{l}\text { loT } \\
\text { Spend as } \\
\text { a Per- } \\
\text { centage } \\
\text { of Reve- } \\
\text { nue }\end{array}$ \\
\hline $\begin{array}{l}\text { Travel, } \\
\text { transportation, and } \\
\text { hospitality }\end{array}$ & $\$ 128.87$ & $\$ 21,491.02$ & $0.60 \%$ \\
\hline $\begin{array}{l}\text { Industrial } \\
\text { manufacturing }\end{array}$ & $\$ 121.28$ & $\$ 21,157.43$ & $0.57 \%$ \\
\hline $\begin{array}{l}\text { Media and } \\
\text { entertainment }\end{array}$ & $\$ 47.15$ & $\$ 8,241.67$ & $0.57 \%$ \\
\hline $\begin{array}{l}\text { Telecommunica- } \\
\text { tions }\end{array}$ & $\$ 110.67$ & $\$ 20,223.81$ & $0.55 \%$ \\
\hline Utilities & $\$ 67.74$ & $\$ 14,411.54$ & $0.47 \%$ \\
\hline $\begin{array}{l}\text { Banking and } \\
\text { financial } \\
\text { services }\end{array}$ & $\$ 117.35$ & $\$ 26,425.66$ & $0.44 \%$ \\
\hline High tech & $\$ 96.91$ & $\$ 24,717.54$ & $0.39 \%$ \\
\hline Automotive & $\$ 93.51$ & $\$ 26,888.64$ & $0.35 \%$ \\
\hline $\begin{array}{l}\text { Healthcare and life } \\
\text { sciences }\end{array}$ & $\$ 56.20$ & $\$ 16,986.36$ & $0.33 \%$ \\
\hline Retail & $\$ 41.80$ & $\$ 13,473.16$ & $0.31 \%$ \\
\hline Insurance & $\$ 77.67$ & $\$ 25,990.91$ & $0.30 \%$ \\
\hline $\begin{array}{l}\text { Consumer package } \\
\text { goods }\end{array}$ & $\$ 41.20$ & $\$ 17,430.42$ & $0.24 \%$ \\
\hline Energy & $\$ 74.89$ & $\$ 33,686.29$ & $0.22 \%$ \\
\hline
\end{tabular}

Source: Columbus, 2016.

\section{Greening the tourism sector}

The development of the travel industry, among numerous benefits, also results in significant contribution to GHG emissions, increased nonrenewable energy and water consumption, waste generation, damage to local terrestrial and marine biodiversity and threats to the survival of local cultures, built heritage and traditions (United Nations Environment Programme and World Tourism Organization, 2012). Even the Internet, mobile technology, and the IoT immensely improve the tourism sector by connecting people, places, organizations, and facilities in unprecedented ways, and their rapid growth at the same time results in increased waste, GHG emissions and/or the consumption of natural and non-renewable raw materials. The resource-intensive manufacturing and utilization of ICT products and systems and escalating volumes of solid and toxic waste may have negative effects on human and environment (Vidas-Bubanja, 2014), and as such represent major challenges towards sustainable development and sustainable place for living. Hence, greening the tourism industry, or any other sector, involves efficiency improvements in energy, water, and waste systems, which consequently saves money and prevents pollution. Alongside cost savings and environmental benefits, the greening actions lead to other benefits, such as health, liability as well as public image.

Some of the actions that significantly contribute to pollution prevention and reduction include: using motion sensor light switches, installing recycling bins, using products and materials with recycled content, reuse materials, reduce printing or use double-sided printing, use reusable cups and dishes, substitute hazardous cleaning agents with friendlier biodegradable products, etc. In order to minimize the negative impacts of technology applications on human and environment, the greening process consists of technology application development without damaging, overexploiting or depleting natural resources, energy consumption reduction, the creation of products which can be completely reused or reclaimed, decreasing the amount of waste and pollution during manufacturing and utilization. In other words, the green, environmental or clean technology involves environmental sustainable designing, manufacturing, using and disposing, with minimal or no impact to the environment (Fig. 1), and as a such represents a central enabling technology supporting green growth and the development of the green economy (Green ICT, n.d). According 
to the United Nations Environment Programme and the World Tourism Organization (2012), green economy can be defined as one of the effects of improved quality of life and social equity accompanied with preserved and enhanced environmental quality. Even though it is expected that green ICTs will make a future greener, in which human will be more aware of technology impact on the environment and human health, there are technical, commercial and regulatory barriers to their introduction, development, and implementation.

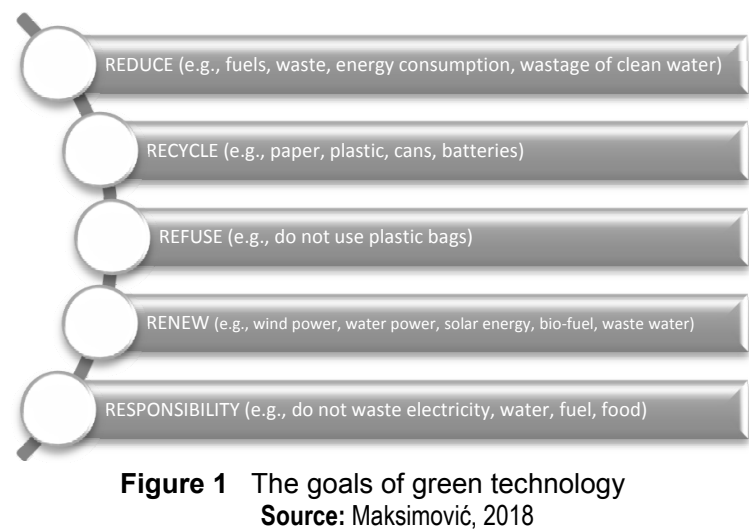

The increasing number of smart devices has a huge impact on the travel and hotel industry. Hence, the essence of smart and at the same time sustainable, green or responsible tourism is in the use of green ICTs. The utilization of sensors, cameras and smartphones, Cloud services and IoT, Big Data analysis and collaboration of the web and mobile services, significantly contribute to greening the tourism industry. Some of the benefits the advent and application of novel green technologies offer are (Young, 2015; Mimos, 2015; Morris, 2016; Travel Tech Inc., 2017; Emerging Technology in Travel, 2017):

- With the IoT the interactive mobility solutions can be offered to potential tourists in the sense of virtual tours of a destination before booking. Through services such as e-demonstrator (to offer a unique cultural experience and activities), and e-tour guide (for personalized travel guide services to enrich travel experience and ensure tourists' safety and security throughout the journey), tourists are experiencing cultural and heritage destination.

- The use of touch screens through mobile tours and apps enable travelers to find their gate at the airport, to experience smoother and faster verification process at the lanes (consequently lead to lower cases of missed flights and shorter transit periods) while portable devices and users can be tracked with the help of IoT. Thanks to the IoT gate agents can locate late passengers and expedite departures.

- The IoT solutions can help travelers from route planning to lodging arrangement and journey planning. Ubiquitous gadgets help travelers to record time, speed/pace, distance, location, elevation and allow instant communication with similar peers en route or who have checked into the same location, as well as to instantly look for a help if they get into any trouble at any point of their journey.

- With the help of mobile Intelligent Travel Assistance (Fig. 2) tourists can manage and organize travel information during their trip through real-time translation of written words and accessing layers of digital information about city environments, landmarks and transportation. Such solutions are able to work with a consolidated itinerary automatically modifying all travel plans and informing family members or business associates in the case of any change.

- Through the smartphones and apps, guests can alert the resort staff about their arrival, so that upon entering the room, the room temperature and the lights already adjust to guest needs. Moreover, with the help of IoT, smart devices (e.g. smart thermostats, coffee makers, connected mirrors, robot butlers, smart light bulbs) can work together to automatically personalize environmental conditions for guests based on their proximity and movement patterns. For instance, smartphone can communicate with the door panel so that the door unlocks automatically when the guest is near his/her room, while lighting and temperature can be automatically set based on sensor data from IoT devices, therefore increasing efficiency and eliminating waste.

- Hotels can automatically send electronic key cards to their guests' mobile devices, providing a comprehensive self-check-in and keyless room entry. Moreover, for returning guests, hotels can save room preferences and automatically personalized content at each visit. Hotels can use IoT to keep tabs on guests' electricity or water 
consumption, automatically alerting the front desk if consumption exceeds a preset limit. Furthermore, if the hotel has an IoTenabled elevator which can send information to technicians for immediate repair, the hotel authorities do not have to worry about the repair process.

- IoT technologies can facilitate surveillance of travel-related diseases - infectious diseases and other adverse health outcomes in returning travelers, foreign visitors and immigrants.

- Using IoT technologies, patients' health conditions can be monitored remotely and continuously as they enjoy a vacation while recuperating after a medical procedure. The vacation phase of posttreatment includes follow-up for medical procedures via teleconsultation and support the continuity of care.

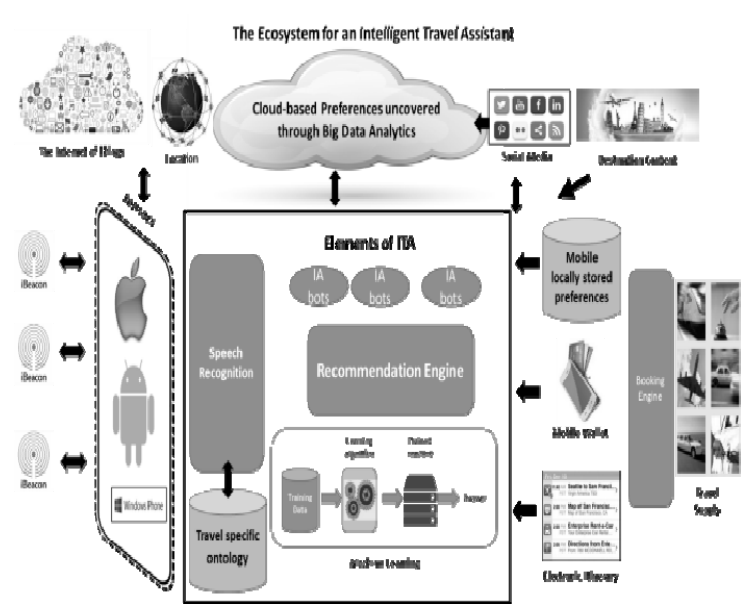

Figure 2 The Ecosystem for an Intelligent Travel Assistant

Source: Travel Tech Inc., 2017.

These application cases are just examples how novel green technology solutions can contribute to the greening tourism sector, making it sustainable and directly affect revenue generation and customer retention. However, to achieve full potential in the green ICTs utilization in the tourism sector, it is necessary to deal with the privacy and security issues of customers' data. Only by guaranteeing the privacy and security of guest information can tourists and travelers' satisfaction and trust be enhanced (Dickson, 2016). A deep dependence of the green tourism sector on technology and network services requires the demand for trained and knowledgeable staff. Additionally, adequate green management activities through strategic and organizational changes are also required. Only in this way the whole business mod$\mathrm{el}$, and the tourism industry can be revolutionized.

\section{Green marketing role in the tourism sector}

Environmental concerns regarding soil, air and water pollution and GHG emissions have been in focus of the world community since the 1960s (Garg, 2015). It is anticipated that the condition of the environment will worsen in the years to come. Some of the expectations include the rise of average temperature between $1.8{ }^{\circ} \mathrm{C}$ and $4.0{ }^{\circ} \mathrm{C}$ during the $21^{\text {st }}$ century as the consequence of the burning of fossil fuels. Climate-change-induced calamities alone are projected to account for 500,000 deaths and $\$ 340$ billion in damages by 2030 , compared to recent 315,000 and $\$ 125$ billion. Furthermore, it is projected that, by 2025, two-thirds of the world's population will not have access to potable water (Ottman, 2011). Evidently, these climate changes and global warming will affect the tourism sector. Until recently, only non-Governmental organizations, environmental activists, and bodies have been active in this sphere, but nowadays people become aware more than ever before of diverse products and service impact on the environment and human health. Therefore, business organizations have started to integrate environmental concerns of the society into organizational activities, which results in the realization of green concepts such as green design, green production, green packaging, green pricing, green logistics, green promotion, green marketing, and so on. In other words, adopting green management principles and requirements is crucial in achieving economic and social benefits. Green management can be defined as an attempt of every individual to move towards earth-centered and nurturing mode (Zahedi, 2012). As a way to promote the green and sustainable management, green marketing is adopted today as a marketing strategy by many companies in developed countries (Garg, 2015). Green marketing has evolved over a period of time through three phases (Jain, Naidu, \& Payasi, 2010; Jayakumar, 2017):

1. Ecological green marketing - during this period all marketing activities were focused to overcome and provide solutions for environmental problems.

2. Environmental green marketing - this period was dedicated to development of clean technologies, and new products, which take 
care of issues regarding pollution and waste.

3. Sustainable green marketing - this phase came to prominence in the late 1990 s and early 2000 s.

Hence, the increasing trend of adopting ecofriendly business, technologies and services has offered new business opportunities for making a profit and led to the emergence of the term green marketing (Fig. 3) (Jain, 2013; Kumar \& Ghodeswar, 2015). Green marketing is the part of all the activities designed to generate and facilitate any changes intended to satisfy the requirements of consumers and society without harming the environment (Polonsky, 1994).

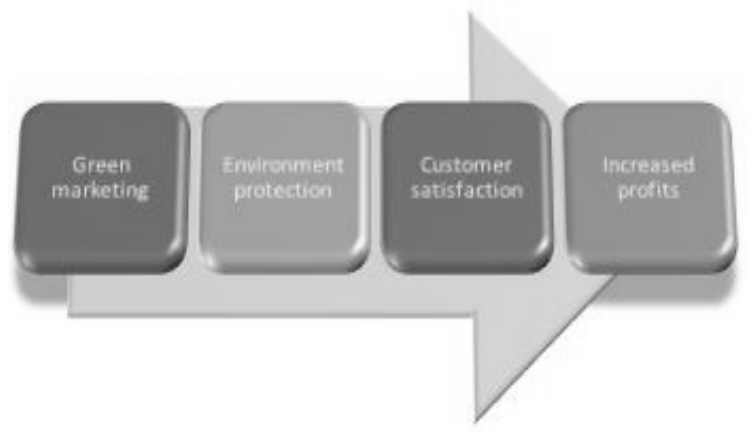

Figure 3 Benefits of going green Source: Jain, 2013

In other words, green marketing represents the efforts of an organization in designing, promoting, pricing and distributing products with minimal or no impact on the environment (Pride \& Ferrell, 1993). Thus, green marketing is implemented in practice through the application of environmentally acceptable strategies (Bošković \& Štoković, 2001):

- Development and fulfillment of market segments that have developed environmental awareness;

- Ensuring the implementation of environmental standards and their incorporation into business activities;

- Improving the quality standards of products and packaging for the product;

- Establishment of promotional strategies adapted to new segments of green consumers by working with groups of Environmental Protection;

- Improvement of environmental standards and launching green initiatives;

- Ecolabel certifications promotions.
These strategies can also be applied to tourism resulting in the following effects of green marketing on businesses: (Polonsky \& Rosenberger, 2001):

- Reduce costs - by adopting green standards in production processes, available resources are consumed in better manners, which leads to cost reduction.

- Gaining competitive advantage - by offering green products that green consumers want to buy, meet the needs of the market, satisfies customers and leads to increased profitability.

- Improving business processes - the greening process can be considered as an opportunity to improve products, develop new business strategy, mission, vision, etc. taking into account the guidelines of green marketing.

As it can be seen, the green marketing is a marketing strategy that has a positive impact on environmental safety and can be regarded as a tool for protecting the environment for the future generation. Therefore, the companies that want to survive in this market have to go green in all aspect of their business (Jayakumar, 2017). Regarding the green tourism, making it successful requires performing adequate management and marketing efforts. Green marketing can be seen as a strategy which implies cooperation between suppliers and sellers, partners as well as rivals, in order to achieve environmentally sustainable development throughout the entire value chain. At the same time, the cooperation of all business functions in achieving profit and long-term, positive contributions to the environment is necessary. In order to gain all the strategic advantages that green management and marketing has to offer to green tourism requires the engagement of all participants, top management, stakeholders and individuals in business (Meler \& Ham, 2012).

\section{Conclusion}

Since travel and tourism industries are able to generate significant social, economic and cultural benefits and development of any region, a large number of tourist destinations are trying to attract the tourists to their destinations in various ways. Achieving smart and green tourism requires certain activities including the production of ecologically safe, recyclable and biodegradable products, using energy efficient operations with minimal or 
no pollution, efficient waste management, conserving cultural and natural assets, etc. Keeping in mind the importance of such sustainable and socially responsible products, processes and services, the technology significantly assists in greening up products and processes. G-IoT as a leading way to achieve numerous benefits alongside minimized harm on the environment and human health will evidently play a significant role in achieving economic and environmental benefits in diverse areas, including the tourism sector. Together with the G-IoT, adequate management and marketing efforts are mandatory in the process of protecting the environment and moving towards sustainable development. Such efforts are known under the terms green management and green marketing and have been recognized as one of the most important business strategies to achieve responsible, sustainable and accessible tourism. SM

\section{References}

Bošković, D., \& Štoković, I. (2001). Total Consumer Satisfaction as a Means to Marketing Globalisation. Zagreb: CROMAR Congress.

Columbus, L. (2016). Where Internet of Things Initiatives Are Driving Revenue Now. Retrieved July 5, 2017 from Forbes:

https://www.forbes.com/sites/louiscolumbus/2015/07/28 /where-internet-of-things-initiatives-are-driving-revenuenow/\#9ecf9f81fa38

Dickson, B. (2016). A Connected World Through loT Will Usher in the Future of Tourism and Travel. Retrieved July 8, 2017 from Motherboard: ). A Connected World Through loT Will Usher in the Future of Tourism and Travel. Motherboard. Retrieved from https://motherboard.vice.com/en_us/article/connecteddevices-through-iot-will-usher-in-the-future-of-tourismand-travel

Garg, A. (2015). Green Marketing for Sustainable Development: an Industry Perspective. Sustainable Development, 23 (5), 301-316.

Green ICT. (n.d.). Retrieved July 6, 2017 from Green ICT: http://greenict.govmu.org/portal/sites/greenict/download .html

lyer, V. R., Chakraborty, S., \& Dey, N. (2015). Advent of Information Technology in the world of Tourism. In R. $\mathrm{N}$., Emerging Innovative Marketing Strategies in the Tourism Industry (pp. 44-53). Hershey: IGI Global.

Jain, P. (2013). Introduction to Green Marketing. Retrieved July 10, 2017 from Durofy: http://durofy.com/introduction-to-green-marketing/

Jain, V., Naidu, G., \& Payasi, S. (2010). Green Marketing \& its Changing Scenario. Management Prudence Journal, 1 (2), 76-80.

Jayakumar, C. (2017). Green marketing and sustainability. Retrieved September 15, 2017 from Academia: http://www.academia.edu/2644250/GREEN_MARKETI NG_AND_SUSTAINABILITY

Kumar, G., \& Ghodeswar, B. (2015). Factors affecting consumers' green product purchase decisions. Marketing Intelligence \& Planning, 33 (3), 330-347.
Maksimovic, M. (2018) Greening the future: Green Internet of Things (G-loT) as a key technological enabler of sustainable development (pp. 283-313). In N. Dey, A. E. Hassanien, C. Bhatt, A. S. Ashour, \& S. C. Satapathy (Eds.) Internet of Things and Big Data Analytics toward Next Generation Intelligence, Studies in Big Data, Cham: Springer International Publishing.

Maksimovic, M., \& Gavrilovic, Z. (2016). Connecting sciences in green: Internet of Things and Economy. ENTECH '16/IV. International Energy Technologies Conference, (pp. 173-182). Istanbul.

Meler, M., \& Ham, M. (2012). Green marketing for green tourism. Retrieved July 22, 2017 from ResearchGate: https://www.researchgate.net/profile/Marcel_Meler/publi cation/266853946_GREEN_MARKETING_FOR_GREE N_TOURISM/links/543d6bcc0cf2d6934ebcf489.pdf

Mimos. (2015). IOT idea book: experiential travel and tourism. Retrieved July 22, 2017 from Mimos Berhad: http://www.mimos.my/wp-content/uploads/2016/01/loTIdea-Book-Experiential-Travel-and-Tourism.pdf

Morris, F. (2016). How the loT is going to transform the travel industry. Retrieved July 15, 2017 from IBM: https://www.ibm.com/blogs/internet-of-things/iot-travelindustry/

Nitti, M., Pilloni, V., Giusto, D., \& Popescu, V. (2017, January 30). IoT Architecture for a Sustainable Tourism Application in a Smart City Environment. Retrieved July 5, 2017 from Hindawi: https://www.hindawi.com/journals/misy/2017/9201640/

Ottman, J. (2011). The New Rules of Green Marketing: Strategies, Tools, and Inspiration for Sustainable Branding. Sheffield: Greenleaf Publishing.

Peeters, P., \& Dubois, G. (2010). Tourism travel under climate change mitigation constraints. Journal of Transport Geography, 18 (3), 447-457.

Polonsky, M. J. (1994). An introduction to green marketing. Retrieved September 12, 2017 from http://escholarship.org/uc/item/49n325b7\#page-8

Polonsky, M. J., \& Rosenberger, P. (2001). Reevaluuating Green Marketing: A Strategic Approach. Retrieved July 15, 2017 from http://www.datadanesh.com/freearticle/Datadanesh.co m-2076.pdf

Pride, W. M., \& Ferrell, O. C. (1993). Marketing - Concepts and Strategies. Boston: Houghton-Mifflin.

Sabre Labs. (2017). Emerging Technology in Travel, 2017 Report . Retrieved September 14, 2017 from Sabre: https://www.sabre.com/labs/emergingtech/files/SabreLa bs_EmergingTechinTravel.pdf

Travel Tech Inc. (2017). Intelligent Travel Assistant Update. Retrieved September 12, 2017 from http://www.traveltechnology.com/2014/08/intelligenttravel-assistance-update/

United Nations Environment Programme and World Tourism Organization. (2012). Tourism in the Green Economy - Background Report. Madrid: UNWTO.

Vidas-Bubanja, M. (2014). Implementation of green ICT for sustainable economic development. 37th International Convention on Information and Communication Technology, Electronics and Microelectronics MIPRO, 2014 (pp. 1592-1597). Washington: IEEE.

World Travel \& Tourism Council (2016). Travel and Tourism - Economic impact 2016 World, Retrieved from https://www.wttc.org//media/files/reports/economic\%20impact\%20research/r egions \%202016/world2016.pdf 
Young, A. (2015). The Internet of Things: The Impact on the Travel and Hotel Industry. Retrieved July 12, 2017 from Hospitalitynet:

http://www.hospitalitynet.org/news/4071511.html
Zahedi, S. (2012). Tourism and global warming. How green management can help. Retrieved July 15, 2017 from http://www.aabri.com/OC2012Manuscripts/OC12034.pdf

\section{$\triangle$ Correspondence}

\section{Zvjezdana Gavrilović}

Faculty of Business Economics

Semberskih ratara bb, 76300 Bijeljina, Republic of Srpska, Bosnia and Herzegovina

E-mail: zvjezdana.gavrilovic@fpe.unssa.rs.ba 